\title{
PALEOBATIMETRI FORMASI JATILUHUR BERDASARKAN KUMPULAN FORAMINIFERA KECIL PADA LINTASAN SUNGAI CILEUNGSI, KABUPATEN BOGOR, JAWA BARAT
}

\author{
PALEOBATYMETRY OF JATILUHUR FORMATION BASED ON \\ ASSEMBLAGES OF SMALL FORAMINIFERA IN CILEUNGSI RIVER, \\ BOGOR, WEST JAVA
}

\section{Lili Fauzielly, Lia Jurnaliah, Ria Fitriani}

Fakultas Teknik Geologi - Universitas Padjadjaran, Jl. Raya Bandung Sumedang km 21 Jatinangor

\begin{abstract}
ABSTRAK Formasi Jatiluhur di sekitar Sungai Cileungsi merupakan lingkungan laut dangkal (zona neritik) berdasarkan dominasi foraminifera yang dikandungnya. Namun beberapa penelitian terdahulu menyatakan umur Formasi Jatiluhur yang bervariasi. Penelitian paleobatimetri berdasarkan kumpulan foraminifera kecil diharapkan dapat melengkapi kajian detil yang terkait dengan evolusi daerah ini selama Miosen. Pengambilan 30 sampel sedimen dilakukan secara sistematik pada satu lintasan di sepanjang Sungai Cileungsi. Hasil preparasi sampel sedimen dengan metode hidrogen peroksida menghasilkan 57301 individu foraminifera kecil yang terdiri dari 23276 individu foraminifera plangtonik dan 34025 foraminifera bentonik. Untuk mengetahui paleobatimetri, digunakan rasio foraminifera plangtonik dan foraminifera bentonik kecil. Hasil Rasio P/B berkisar antara 4,4 \% - 74,0 \% menunjukkan paleobatimetri Formasi Jatiluhur berkisar antara zona neritik dalam - zona batial atas.
\end{abstract}

Kata kunci: Foraminifera kecil, foraminifera plangtonik, foraminifera bentonik, paleobatimetri, Formasi Jatiluhur.

Naskah masuk : 29 Januari 2018

Naskah direvisi : 27 Maret 2018

Naskah diterima : 30 Agustus 2018

Lili Fauzielly

Fakultas Teknik Geologi - Universitas Padjadjaran, Jl.

Raya Bandung Sumedang Km 21 Jatinangor

Email : lili.fauzielly@unpad.ac.id
ABSTRACT Jatiluhur Formation in the area of Cileungsi River was a shallow marine environment based on the foraminiferas domination. Several previous published papers had suggested age variation of the Jatiluhur Formation. Paleobatimetry study based on small foraminiferas was expected to complete the Miocene evolution analysis of the region. Thirty sediment samples were picked systematically in a section line along Cileungsi River. The hydrogen peroxide preparation of sediment samples produced 57301 small foraminifera. There were 23276 planktonic foraminiferas and 34025 benthic foraminiferas. To understand the paleobathimetry of this research area, we calculated the ratio of planktonic foraminifera and benthic foraminifera $(P / B$ ratio). The $P / B$ ratio is betweeen $4,4 \%$ and $74,0 \%$. The ratio suggests that the paleobathimetry of Jatiluhur Formation is Inner Neritic Zone - Upper Bathyal Zone.

Keywords: Small Foraminifera, planktonic foraminifera, benthic foraminifera, paleobathimetry, Jatiluhur Formation.

\section{PENDAHULUAN}

Foraminifera dapat ditemukan di berbagai lingkungan dari lingkungan payau sampai laut dalam. Kehidupannya sangat dipengaruhi oleh keadaan tempat hidupnya (Valchev, 2003). Menurut Lipps (1979) jumlah spesies foraminifera pada umumnya berubah seiring dengan bertambahnya kedalaman air dan jarak dari pantai sedangkan kelimpahan foraminifera biasanya mencapai titik puncak di dekat perbatasan paparan (shelf). Selanjutnya Mendes, et al. (2004) 


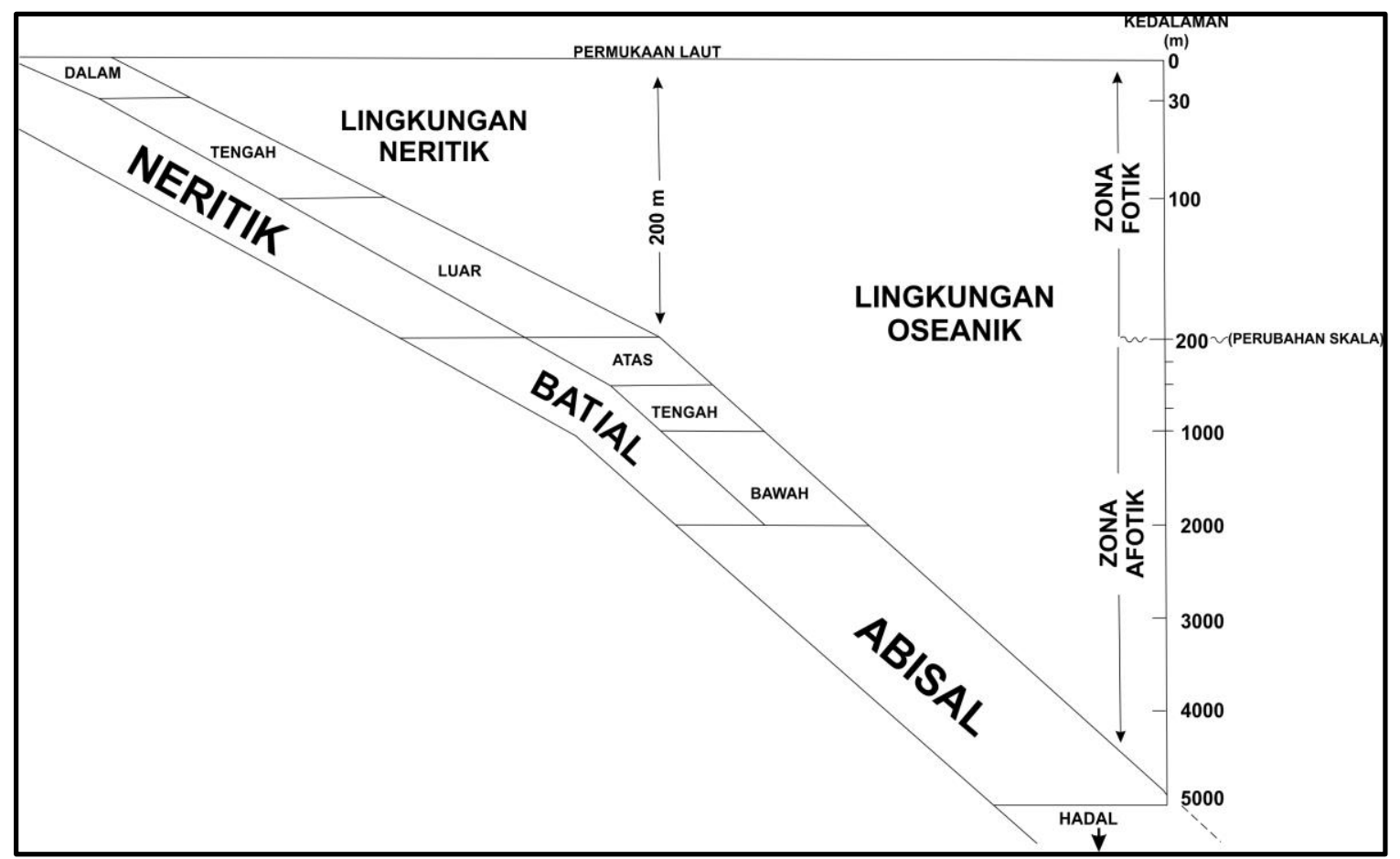

Gambar 1. Zona Batimetri Lingkungan Laut (modifikasi dari Berggren, 1998 dalam Haq dan Boersma, 1998).

menyatakan jumlah foraminifera bentonik dan indeks diversitas berhubungan dengan batimetri (kedalaman air).

Penentuan paleobatimetri merupakan salah satu cara dalam penentuan lingkungan purba. Menurut Berggren (1998) dalam Haq \& Boersma (1998) lingkungan laut secara umum terbagi menjadi 2 divisi utama yaitu Lingkungan Neritik dan Lingkungan Oseanik. Neritik (Litoral) terbagi menjadi 3 (tiga) zona, yaitu Neritik dalam (Inner Neritic): 0-30 m; Neritik tengah (Middle Neritic): 30-100 m dan Neritik luar (Outer Neritic): 100$200 \mathrm{~m}$. Selanjutnya Lingkungan Oseanik terdiri dari 3 (tiga) zona juga, yaitu zona bathyal (200$2000 \mathrm{~m})$, zona abyssal (2000-5000 m) dan zona hadal $(>5000 \mathrm{~m})$. Zona bathyal terbagi menjadi 3 (tiga) zona, yaitu Batial atas (Upper bathyal): 200$600 \mathrm{~m}$; batial tengah (Middle bathyal): 600-1000 $\mathrm{m}$; batial bawah (Lower bathyal): 1000-2000 m (Gambar 1).

Van Marle (1989) melakukan penelitian terhadap persentase foraminifera plangtonik dari sampel sedimen dasar laut dan membuat kesimpulan bahwa persentase foraminifera plangtonik dapat membantu dalam memperkirakan kedalaman air purba. Metode rasio foraminifera plangtonik dan foraminifera bentonik ini dapat memperkirakan secara cepat dan terpercaya dari paleobatimetri.

Penelitian tentang lingkungan dari Formasi Jatiluhur telah dilakukan oleh beberapa peneliti. Jurnaliah (2006) dan Reza et al., (2016) menyimpulkan lingkungan Formasi Jatiluhur di Daerah Cileungsi merupakan lingkungan laut dangkal berdasarkan dominansi foraminifera bentonik kecilnya. Penelitian paleobatimetri dilakukan untuk merekonstruksi batimetri (kedalaman air) dari Formasi Jatiluhur sehingga dapat diketahui lingkungannya. Hasil penelitian ini diharapkan dapat melengkapi kajian lingkungan yang telah dilakukan oleh peneliti terdahulu.

Lokasi penelitian terletak di lintasan Sungai Cileungsi termasuk ke dalam Formasi Jatiluhur di dalam Peta Geologi Lembar Bogor, Jawa, berumur Miosen Awal (Effendi et al., 1998). Sementara itu, berdasarkan studi biostratigrafi, Mulyasari (1999) menyatakan Satuan Batulempung di Daerah Cileungsi berumur Miosen Awal-Miosen Tengah, sedangkan Reza, et al., (2016) menyimpulkan umur dari Formasi Jatiluhur di Sungai Cileungsi adalah Miosen Tengah-Miosen Akhir. Pada penelitian ini umur 


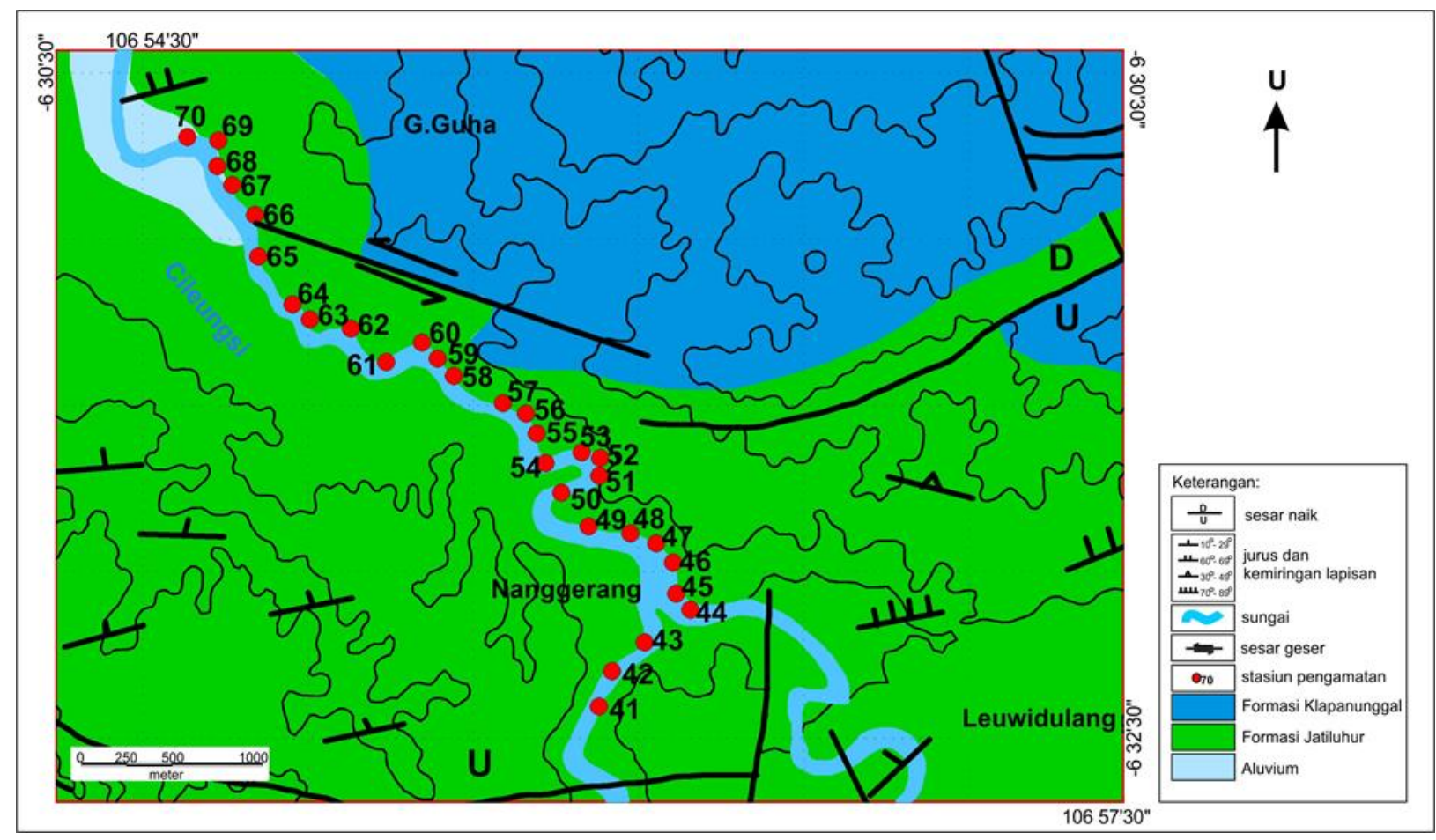

Gambar 2. Peta lokasi pengambilan sampel dalam kompilasi peta geologi Lembar Bogor (Effendi, et al., 1998).

Tabel 1. Klasifikasi dari rasio P/B (Murray, 1976 dan Boersma, 1983 dalam Valchev, 2003).

\begin{tabular}{cc}
\hline Rasio P/B & Lingkungan \\
\hline$<20 \%$ & Neritik dalam (paparan dalam) \\
$20-60 \%$ & Neritik tengah (paparan tengah) \\
$40-70 \%$ & Neritik luar (paparan luar) \\
$>70 \%$ & Batial atas \\
$>90 \%$ & Batial bawah \\
\hline
\end{tabular}

daerah penelitian mengacu pada Effendi et al., (1998) yaitu Miosen Awal.

\section{METODE}

Pengambilan 30 sampel sedimen secara sistematis berdasarkan penampang terukur (Abdurokhim, 2014) dengan interval sekitar 5 (lima) meter dilakukan pada Lintasan Sungai Cileungsi (Gambar 2). Preparasi sampel sedimen untuk analisis foraminifera kecil menggunakan metode hidrogen peroksida (Todd et al., 1965 dalam Kummel \& Raup, 1965; Boltovskoy \& Wright, 1976 dan Jones, 2014). Identifikasi dari foraminifera kecil dilakukan dengan memperhatikan komposisi dan morfologi cangkangnya seperti susunan kamar, jumlah kamar, ornamentasi dan apetur mengacu pada pustaka Loeblich dan Tappan (1994).

Penghitungan jumlah individu foraminifera plangtonik dan foraminifera bentonik dilakukan pada setiap 1 (satu) gram sampel sedimen kering (Murray dan Rohling, 2012). Rasio kedua jenis foraminifera tersebut dihitung dengan menggunakan rumus sebagai berikut:

Rasio $\mathrm{P} / \mathrm{B}=\mathrm{P} /(\mathrm{P}+\mathrm{B})$, dimana $\mathrm{P}$ adalah jumlah individu foraminifera plangtonik dan $\mathrm{B}$ adalah jumlah individu foraminifera bentonik (Valchev, 2003). Hasil penghitungan rasio $\mathrm{P} / \mathrm{B}$ kemudian diklasifikasikan ke dalam zona batimetri menggunakan klasifikasi pada Tabel 1. 


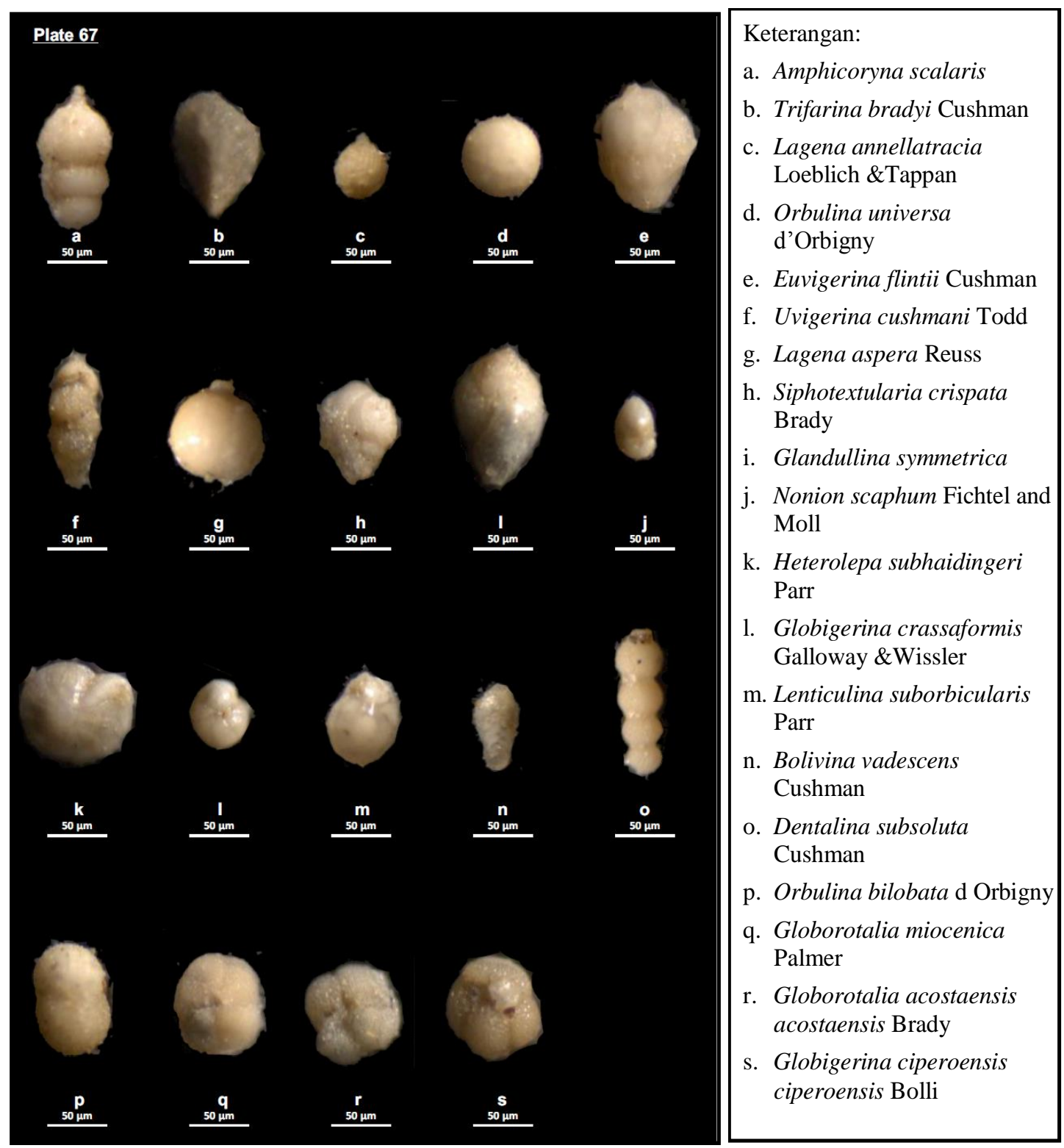

Gambar 3. Foraminifera pada sampel sedimen formasi jatiluhur di Lintasan Sungai Cileungsi.

\section{HASIL DAN PEMBAHASAN}

Litologi daerah penelitian terdiri dari batulempung dengan sisipan batupasir dan batugamping. Berdasarkan penampang stratigrafi dari lintasan Sungai Cileungsi terlihat adanya beberapa kali perubahan jenis litologi di sepanjang Kala Miosen Awal (Gambar 4). Terjadinya perubahan litologi menunjukkan adanya perubahan lingkungan pengendapan (Abdurrokhim, 2014).

\section{Foraminifera}

Berdasarkan analisis foraminifera kecil dari 30 sampel sedimen pada Lintasan Sungai Cileungsi diperoleh jumlah total individu foraminifera sebesar 57301 dengan komposisi foraminifera plangtonik sebesar 23276 dan foraminifera bentonik sebesar 34025 (Gambar 3) Terdapat 5 (lima) sampel sedimen yang tidak (jarang) mengandung foraminifera kecil, yaitu sampel 52, sampel 50, sampel 49, sampel 46 dan sampel 42. Jumlah individu foraminifera plangtonik dan foraminifera bentonik ditemukan paling banyak pada sampel 68 (Tabel 2). Perubahan jumlah individu foraminifera plangtonik dan foraminifera bentonik Kala Miosen Awal dari tua ke muda menunjukkan adanya perubahan lingkungan (Tabel 3). 
Tabel 2. Distribusi foraminifera formasi jatiluhur pada lintasan S. Cileungsi.

\begin{tabular}{|c|c|c|c|c|c|c|c|c|c|c|c|c|c|c|c|c|c|c|c|c|c|c|c|c|c|c|c|c|c|c|c|c|}
\hline No & Jumlah Spesies & 70 & 69 & 68 & 67 & 66 & 65 & 64 & 63 & 62 & 61 & 60 & 59 & 58 & 57 & 56 & 55 & 54 & 53 & 52 & 51 & 50 & 49 & 48 & 47 & 46 & 45 & 44 & 43 & 42 & 41 & Jumlah \\
\hline & Alphelophragmina semilineata Belford & 0 & 0 & 0 & 0 & 0 & 0 & 8 & 0 & 0 & 0 & 0 & 0 & 0 & 0 & 0 & 0 & 0 & 0 & 0 & 0 & 0 & & 0 & 0 & 0 & 0 & 0 & 0 & 0 & 0 & 8 \\
\hline & Ammomassilina alveoliniformis, Millett & 0 & 0 & 0 & 0 & 0 & 0 & 0 & 0 & 0 & 0 & 0 & 0 & 0 & 8 & 0 & 0 & 0 & 0 & 0 & 0 & 0 & & 0 & 0 & 0 & 0 & 0 & 0 & 0 & 0 & 0 \\
\hline & Amphicoryna scalaris, Batsch & 128 & 64 & 32 & 192 & 0 & 0 & 0 & 0 & 0 & 0 & 8 & 0 & 0 & 0 & 0 & 0 & 0 & 0 & 0 & 0 & 0 & & 0 & 0 & 0 & 0 & 0 & 0 & 0 & 0 & 424 \\
\hline 4 & Amphicoryna separans & 256 & 96 & 96 & 0 & 0 & 0 & 0 & 0 & 0 & 0 & 0 & 0 & 0 & 0 & 0 & 0 & 0 & 4 & 0 & 0 & 0 & & 0 & 0 & 0 & 0 & 2 & 4 & 0 & 0 & 458 \\
\hline & Amphic & 0 & 0 & 0 & 0 & 0 & 0 & 0 & 0 & 0 & 0 & 0 & 0 & 0 & 0 & 16 & 0 & 0 & 0 & 0 & 0 & 0 & & 0 & 0 & 0 & 0 & 0 & 0 & 0 & 0 & 16 \\
\hline 6 & Amphistegina lesson & 0 & 48 & 0 & 0 & 0 & 1472 & 0 & 0 & 0 & 64 & 192 & 0 & 8 & 112 & 0 & 8 & 8 & 0 & 1 & 0 & 0 & & 0 & 0 & 0 & 0 & 0 & 0 & 0 & 0 & 1913 \\
\hline & Anomalinoides globusus, Chapman \& Parr & 0 & 80 & 96 & 0 & 0 & 48 & 0 & 0 & 32 & 0 & 32 & 0 & 0 & 24 & 0 & 0 & 0 & 0 & 0 & 0 & 0 & & 1 & 0 & 0 & 0 & 0 & 0 & 0 & 32 & 345 \\
\hline 8 & Bolivina nitida, Brady & 128 & 112 & 64 & 0 & 0 & 16 & 0 & 32 & 0 & 112 & 0 & 192 & 0 & 0 & 160 & 0 & 0 & 0 & 0 & 0 & 0 & & 0 & 0 & 0 & 0 & 0 & 0 & 0 & 0 & 816 \\
\hline 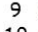 & Bolivina vadescens, Cushman & 192 & 192 & 32 & 64 & 264 & & 48 & 224 & 248 & 16 & 72 & 64 & 32 & 8 & 48 & 0 & 0 & 0 & 0 & 0 & 0 & & 0 & 3 & 0 & 0 & 30 & 54 & 0 & 32 & 1623 \\
\hline 10 & Cibicides lobatulus, Walker \& Jacob & 0 & 0 & 576 & 0 & 8 & 32 & 80 & 16 & 0 & 0 & 8 & 0 & 0 & 56 & 0 & 0 & 0 & 0 & 0 & 0 & 0 & & 0 & 0 & 0 & 0 & 0 & 0 & 0 & 0 & 776 \\
\hline 11 & Cibicides subhaid & 0 & 0 & 0 & 0 & 48 & 96 & 0 & 336 & 0 & 0 & 24 & 0 & 80 & 0 & 24 & 48 & 0 & 0 & 0 & 80 & 0 & & 1 & 0 & 0 & 0 & 14 & 0 & 0 & 0 & 751 \\
\hline 12 & Dentalina ruidarostrata, Loeblich \& Tappan & 0 & 96 & 0 & 0 & 0 & 0 & 8 & 0 & 0 & 336 & 24 & 0 & 0 & 0 & 0 & 0 & 0 & 0 & 0 & 0 & 0 & & 2 & 0 & 0 & 0 & 0 & 0 & 0 & 0 & 466 \\
\hline 13 & Dentalina subsoluta, Cushn & 0 & 240 & 32 & 64 & 0 & 0 & 0 & 0 & 0 & 288 & 40 & 0 & 0 & 0 & 8 & 0 & 0 & 0 & 1 & 0 & 0 & & 1 & 0 & 0 & 1 & 2 & 0 & 0 & 0 & 677 \\
\hline 14 & Elphidium neosimplex : & 0 & 0 & 128 & 0 & 0 & 0 & 0 & 0 & 0 & 0 & 0 & 0 & 0 & 0 & 0 & 0 & 0 & 0 & 0 & 0 & 0 & & 0 & 0 & 0 & 0 & 0 & 0 & 0 & 0 & 128 \\
\hline 15 & Elphidium simplex, Cushman & 0 & 0 & 64 & 0 & 8 & 0 & 0 & 16 & 16 & 0 & 48 & 176 & 0 & 8 & 0 & 0 & 0 & 0 & 0 & 0 & 0 & & & 0 & 0 & 0 & 0 & 0 & 0 & 0 & 336 \\
\hline & & & & 96 & 0 & 1416 & 16 & 0 & 368 & 48 & & 16 & & & & 112 & 24 & 42 & 40 & & 256 & 0 & & & & & & 12 & 0 & & & 2523 \\
\hline & Euvvigerina flintii $\mathrm{C}$ & 32 & 0 & 0 & 256 & & 0 & & 80 & 0 & 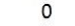 & 0 & 0 & 616 & 0 & 0 & 16 & & & 0 & 0 & & & & & v & 0 & & & 0 & & 1009 \\
\hline 18 & Glandullina symr & 0 & 16 & 32 & 128 & 0 & 0 & 0 & 32 & 0 & & 0 & 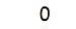 & & 8 & 0 & & 0 & 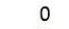 & 0 & 0 & & & & & 0 & 0 & 12 & & 0 & & 228 \\
\hline & Globulin & 96 & 144 & & & 8 & 0 & 0 & & 0 & 0 & 0 & 0 & 0 & 0 & 0 & 0 & 0 & 0 & 0 & 0 & & & & & & 0 & 22 & S & 0 & & 272 \\
\hline & Gyroidina neosoldanii & 96 & 0 & 0 & 0 & 0 & 0 & 8 & 0 & 120 & 0 & 96 & 16 & 16 & 0 & 0 & & 0 & & 0 & 0 & & & 3 & & & 0 & 0 & 0 & 0 & 0 & 356 \\
\hline & Heterol & 192 & 64 & 480 & 0 & 192 & 32 & 40 & 464 & 256 & 0 & 0 & 144 & 96 & 32 & 80 & 0 & 0 & 0 & 0 & 344 & 0 & & 0 & & 0 & 0 & 0 & 2 & 0 & 24 & 2442 \\
\hline & Hetero & 288 & 304 & 1312 & 128 & 0 & 192 & 1176 & 1232 & 168 & 32 & 48 & 432 & 440 & 776 & 64 & 1464 & 290 & 728 & 0 & 88 & 0 & & 10 & & 0 & 0 & 178 & 276 & 0 & 1568 & 11397 \\
\hline 23 & Hogliindina $e$ & & & & & 0 & & & & 0 & 0 & 0 & 0 & & 0 & 0 & 0 & 0 & 0 & 0 & 0 & 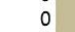 & & 0 & 0 & 1 & 0 & 0 & 0 & 0 & & 1 \\
\hline 24 & ushman & 160 & 0 & 0 & 0 & 0 & 0 & 0 & 0 & 0 & 0 & 0 & 0 & 0 & 0 & 0 & 0 & 0 & 0 & 0 & 0 & 0 & & 1 & 2 & 0 & 0 & 0 & 0 & 0 & 0 & 163 \\
\hline & a, Loeblich \& Tappan & 160 & 112 & 32 & 128 & 8 & 0 & 0 & 0 & 48 & 16 & 0 & 0 & 0 & 0 & 0 & 0 & 0 & 0 & 0 & 0 & 0 & & 1 & 0 & 0 & 0 & 6 & 0 & 0 & & 511 \\
\hline 26 & Lagena & & & 0 & 64 & 0 & 0 & 0 & 0 & 0 & 0 & 8 & 0 & 0 & 0 & 0 & 0 & 0 & 0 & v & 0 & 0 & & 0 & 0 & 0 & 0 & 0 & 0 & 0 & & 72 \\
\hline 27 & Lenticulina doma & 256 & 0 & 0 & 0 & 0 & 48 & 40 & 0 & 8 & 16 & 8 & 0 & 0 & 32 & 160 & 0 & 16 & 0 & 0 & 0 & 0 & & 0 & 0 & 0 & 0 & 0 & 0 & 0 & 0 & 584 \\
\hline 28 & Lenticulina suborbi & 0 & 48 & 0 & 0 & 272 & 0 & 0 & 0 & 240 & 640 & 320 & 32 & 104 & 40 & 376 & 40 & 14 & 24 & 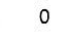 & 0 & 0 & & 0 & 0 & & 0 & 0 & 0 & 0 & & 2150 \\
\hline 29 & Massilina mi & 0 & 0 & 0 & 0 & 0 & 0 & 0 & 0 & 96 & & 0 & 0 & 0 & 0 & 0 & 0 & 0 & 0 & 0 & 0 & 0 & & 2 & 0 & 0 & 0 & 0 & 2 & 0 & & 100 \\
\hline 30 & aplex Cushman \& Todd & 32 & 32 & 0 & 0 & 0 & 0 & 0 & 0 & 0 & 0 & 8 & 0 & 0 & 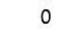 & 0 & 0 & 0 & U & 0 & 0 & 0 & & 1 & 0 & 0 & 0 & 0 & 0 & 0 & & 73 \\
\hline 31 & Non & 0 & 0 & 0 & 64 & 264 & 0 & 24 & 48 & 0 & 0 & 0 & 208 & 0 & 0 & 8 & 136 & 14 & 144 & 0 & 0 & 0 & & & 0 & & 0 & 2 & 4 & 0 & 0 & 916 \\
\hline 32 & \& Wissler & 0 & 0 & 0 & 0 & 0 & 0 & 0 & 0 & 0 & 16 & 32 & 0 & 0 & 0 & 0 & 0 & 0 & 0 & 0 & 0 & 0 & & 0 & 0 & 0 & 0 & 0 & & 1 & 24 & 73 \\
\hline 33 & Plan & 0 & 0 & 0 & 0 & 0 & 0 & 0 & 160 & 0 & 0 & 0 & 0 & 0 & 8 & 0 & 0 & 0 & 0 & 0 & 0 & 0 & & 0 & 0 & 0 & 0 & 0 & & 0 & 0 & 168 \\
\hline 34 & Pseu & 0 & 48 & 0 & 0 & 0 & 0 & 0 & 0 & 0 & 0 & 16 & 0 & 0 & 8 & 0 & 0 & 0 & 0 & 0 & 0 & 0 & & 0 & & & 0 & 0 & & 0 & & 72 \\
\hline 35 & Pyg & 0 & 0 & 0 & 0 & 0 & 0 & 0 & 0 & 0 & 0 & 0 & 0 & 0 & 0 & 0 & 0 & 0 & 24 & 0 & 0 & - & & 1 & & 0 & 0 & 2 & & 0 & 8 & D \\
\hline 36 & ch \& Tappan & 0 & 0 & 0 & 0 & 0 & 16 & 0 & 0 & 0 & 0 & 0 & 112 & 8 & 8 & 0 & 48 & 2 & 0 & 0 & 0 & 0 & & 0 & & & 0 & 0 & & 0 & 0 & 194 \\
\hline 37 & Quir & & 0 & 0 & 0 & 0 & 0 & 0 & 0 & 0 & 0 & 0 & 0 & 0 & 0 & 16 & 0 & 0 & 32 & 0 & 0 & 0 & & & & & 0 & 0 & & 0 & 0 & 8 \\
\hline 38 & Tappan & 288 & 0 & 0 & 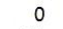 & 0 & 0 & 0 & 0 & 0 & 0 & 0 & 0 & S & 0 & 0 & 40 & 0 & 0 & 0 & 0 & 0 & & 0 & & 0 & 0 & 0 & & 0 & 0 & 328 \\
\hline 39 & & 0 & 0 & 0 & 64 & 0 & 0 & 0 & 0 & 0 & 0 & 8 & 0 & 0 & 0 & v & 0 & 0 & 0 & 0 & 0 & 0 & & & & 0 & 0 & 0 & & 0 & 0 & 72 \\
\hline & & 0 & 0 & 0 & 0 & 8 & 0 & 0 & 0 & 0 & 0 & 0 & 32 & 0 & 0 & 48 & 0 & 0 & 0 & 0 & 0 & 0 & & 0 & & 0 & 0 & 2 & & 0 & 0 & 92 \\
\hline & Said & 0 & 0 & 0 & 0 & 0 & 0 & 0 & 0 & 0 & 0 & 0 & 0 & 0 & 0 & 0 & 0 & 0 & 0 & 0 & 0 & 0 & & & & & 0 & 0 & & 0 & 8 & 12 \\
\hline 42 & Tex & 0 & 0 & 0 & 64 & 112 & 0 & 0 & 0 & 0 & 0 & 0 & 16 & 0 & 0 & 0 & 0 & & 0 & 0 & 0 & 0 & & 0 & & 0 & 0 & 0 & & 0 & 0 & 6 \\
\hline 43 & & 0 & 0 & 0 & 256 & 0 & 0 & 8 & 16 & 0 & 0 & 40 & 16 & 0 & 0 & 8 & 8 & 0 & 0 & 0 & 0 & 0 & & 0 & & 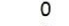 & 0 & 0 & & 1 & 8 & 363 \\
\hline & Uvigerina canariensis, d'Orbigny & 0 & 0 & 32 & 0 & & & & & 88 & & & 16 & 0 & 160 & 208 & 112 & 2 & 56 & 0 & 40 & 0 & & 0 & & 0 & 0 & 4 & 0 & 0 & 0 & 718 \\
\hline & $\begin{array}{l}\text { Uvigerina cushmani Todd } \\
\text { Total }\end{array}$ & & & 32 & & & & & & & & & & & & & & & & & & & & & & & & & & $\frac{0}{2 r}$ & $\frac{0}{12}$ & $\frac{112}{34025}$ \\
\hline
\end{tabular}


Tabel 2. Distribusi foraminifera formasi jatiluhur pada lintasan S. Cileungsi.

\begin{tabular}{|c|c|c|c|c|c|c|c|c|c|c|c|c|c|c|c|c|c|c|c|c|c|c|c|c|c|c|c|c|c|c|c|c|}
\hline No & Nomor Sample & 70 & 69 & 68 & 67 & 66 & 65 & 64 & 63 & 62 & 61 & 60 & 59 & 58 & 57 & 56 & 55 & 54 & 53 & 52 & 51 & 50 & 49 & 48 & 47 & 46 & 45 & 44 & 43 & 42 & 41 & Jumlah \\
\hline$\overline{1}$ & Globigerina crassaformis, Galloway \& Wissler & 0 & 0 & 0 & 192 & 0 & 0 & 0 & 0 & 0 & 0 & 0 & 0 & 0 & 0 & 0 & 0 & 0 & 0 & 0 & 0 & 0 & & 0 & 0 & 0 & 0 & 0 & 0 & 0 & 0 & 192 \\
\hline 2 & Globigerina ciperoensis ciperoensis, Bolli & 0 & 128 & 224 & 1088 & 8 & 0 & 0 & 0 & 0 & 0 & 0 & 0 & 0 & 32 & 0 & 0 & 0 & 0 & 0 & 0 & 0 & & 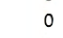 & 0 & 0 & 0 & 0 & 0 & 0 & 0 & 1480 \\
\hline 3 & Globigerina nepenthes, Todd & 128 & 64 & 224 & 0 & 0 & 0 & 0 & 0 & 0 & 0 & 8 & 0 & 0 & 48 & 0 & 0 & 0 & 0 & 0 & 0 & 0 & & 0 & 3 & 1 & 0 & 0 & 0 & 0 & 0 & 476 \\
\hline 4 & Globigerina praebulloides, Blow & 768 & 176 & 960 & 0 & 0 & 0 & 40 & 160 & 136 & 496 & 0 & 64 & 24 & 152 & 120 & 40 & 2 & 24 & 0 & 64 & 0 & & 0 & 0 & 0 & 0 & 6 & 0 & 0 & 0 & 3232 \\
\hline 5 & Globigerinoides altiaperturus, Bolli & 0 & 32 & 0 & 0 & 0 & 0 & 0 & 0 & 0 & 0 & 0 & 0 & 0 & 0 & 0 & 0 & 0 & 0 & 0 & 0 & 0 & & 0 & 0 & 0 & 0 & 0 & 0 & 0 & 0 & 32 \\
\hline 6 & Globigerinoides bisphericus, Todd & 0 & 112 & 0 & 0 & 0 & 0 & 0 & 0 & 0 & 16 & 0 & 0 & 0 & 0 & 0 & 0 & 0 & 0 & 0 & 56 & 0 & & 3 & 0 & 0 & 0 & 0 & 0 & 1 & 0 & 188 \\
\hline 7 & Globigerinoides conglobatus, Brady & 0 & 224 & 0 & 0 & 0 & 0 & 0 & 0 & 0 & 0 & 56 & 16 & 0 & 0 & 0 & 0 & 4 & 0 & 0 & 8 & 1 & & 0 & 0 & 0 & 0 & 0 & 0 & 0 & 0 & 309 \\
\hline 8 & Globigerinoides diminutus, Bolli & 0 & 0 & 96 & 0 & 0 & 0 & 0 & 0 & 0 & 0 & 0 & 0 & 0 & 0 & 0 & 0 & 0 & 0 & 0 & 0 & 0 & & 0 & 0 & 0 & 0 & 0 & 0 & 0 & 0 & 96 \\
\hline 9 & Globigerinoides immaturus, LeRoy & 640 & 240 & 1344 & 0 & 80 & 48 & 192 & 656 & 0 & 832 & 576 & 480 & 248 & 96 & 80 & 72 & 2 & 128 & 0 & 208 & 1 & & 23 & 16 & 0 & 8 & 12 & 22 & 1 & 128 & 6133 \\
\hline 10 & Globigerinoides trilobus, Reuss & 288 & 0 & 0 & 0 & 0 & 0 & 0 & 0 & 32 & 0 & 80 & 128 & 40 & 112 & 0 & 0 & 2 & 24 & 0 & 128 & 0 & & 9 & 0 & 0 & 0 & 0 & 0 & 0 & 0 & 843 \\
\hline 11 & Globorotalia acostaensis acostaensis, Brady & 672 & 0 & 768 & 1280 & 8 & 16 & 8 & 0 & 16 & 64 & 72 & 16 & 0 & 40 & 32 & 0 & 2 & 8 & 0 & 72 & 1 & & 6 & 2 & 0 & 5 & 0 & 12 & 0 & 16 & 3116 \\
\hline 12 & Globorotalia mayeri Cushman and Ellisor & 0 & 144 & 224 & 0 & 0 & 0 & 8 & 0 & 56 & 0 & 16 & 0 & 0 & 96 & 24 & 8 & 0 & 0 & 0 & 64 & 0 & & 16 & 0 & 0 & 0 & 12 & 0 & 0 & 0 & 668 \\
\hline 13 & Globorotalia miocenica Palmer & 0 & 32 & 64 & 64 & 8 & 0 & 0 & 0 & 0 & 0 & 0 & 16 & 0 & 24 & 0 & 0 & 0 & 0 & 0 & 0 & 1 & & 2 & 0 & 0 & 0 & 2 & 0 & 0 & 0 & 213 \\
\hline 14 & Globorotalia obesa Bolli & 1216 & 272 & 960 & 0 & 184 & 0 & 0 & 96 & 8 & 352 & 32 & 112 & 0 & 80 & 48 & 16 & 0 & 0 & 0 & 40 & 0 & & 11 & 6 & 0 & 3 & 28 & 12 & 0 & 96 & 3572 \\
\hline 15 & Orbulina bilobata d'Orbigny & 320 & 16 & 160 & 64 & 0 & 0 & 0 & 80 & 0 & 0 & 72 & 64 & 0 & 0 & 0 & 0 & 2 & 8 & 0 & 8 & 0 & & 1 & 1 & 0 & 4 & 0 & 0 & 0 & 16 & 816 \\
\hline & Orbulina universa d'Orbigny & 640 & 304 & 160 & 448 & 0 & 0 & 32 & 96 & & 112 & 40 & & 40 & 0 & 0 & 0 & & 16 & 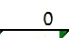 & & 0 & & 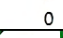 & & 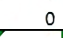 & 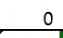 & 0 & 0 & 0 & 8 & 1910 \\
\hline
\end{tabular}


Tabel 3. Lingkungan pengendapan daerah penelitian berdasarkan rasio foraminifera plangtonik dan foraminifera bentonik kecil.

\begin{tabular}{|c|c|c|c|c|c|}
\hline No & $\begin{array}{c}\text { No } \\
\text { Sampel }\end{array}$ & $\begin{array}{l}\text { Jumlah Individu } \\
\text { Foraminifera } \\
\text { planktonik }\end{array}$ & $\begin{array}{l}\text { Jumlah Individu } \\
\text { Foraminifera } \\
\text { bentonik }\end{array}$ & $\begin{array}{c}\text { Rasio } \\
\text { P/B \% }\end{array}$ & LINGKUNGAN \\
\hline 1 & 70 & 4672 & 2304 & 67,0 & neritik luar \\
\hline 2 & 69 & 1744 & 1696 & 50,7 & neritik tengah-neritik luar \\
\hline 3 & 68 & 5184 & 3136 & 62,3 & neritik luar \\
\hline 4 & 67 & 3136 & 1536 & 67,1 & neritik luar \\
\hline 5 & 66 & 288 & 2608 & 9,9 & neritik dalam \\
\hline 6 & 65 & 64 & 1968 & 3,1 & neritik dalam \\
\hline 7 & 64 & 280 & 1440 & 16,3 & neritik dalam \\
\hline 8 & 63 & 1088 & 3024 & 26,5 & neritik tengah \\
\hline 9 & 62 & 256 & 1368 & 15,8 & neritik dalam \\
\hline 10 & 61 & 1872 & 1536 & 54,9 & neritik tengah-neritik luar \\
\hline 11 & 60 & 952 & 1048 & 47,6 & neritik tengah-neritik luar \\
\hline 12 & 59 & 896 & 1456 & 38,1 & neritik tengah \\
\hline 13 & 58 & 352 & 1464 & 19,4 & neritik dalam \\
\hline 14 & 57 & 680 & 1288 & 34,6 & neritik tengah \\
\hline 15 & 56 & 304 & 1336 & 18,5 & neritik dalam \\
\hline 16 & 55 & 136 & 1944 & 6,5 & neritik dalam \\
\hline 17 & 54 & 18 & 388 & 4,4 & neritik dalam \\
\hline 18 & 53 & 208 & 1052 & 16,5 & neritik dalam \\
\hline 19 & 52 & 0 & 2 & $?$ & $?$ \\
\hline 20 & 51 & 648 & 1024 & 38,8 & neritik tengah \\
\hline 21 & 50 & 4 & 0 & $?$ & $?$ \\
\hline 22 & 49 & 0 & 0 & $?$ & $?$ \\
\hline 23 & 48 & 71 & 25 & 74,0 & batial atas \\
\hline 24 & 47 & 30 & 14 & 68,2 & neritik luar \\
\hline 25 & 46 & 1 & 3 & $?$ & $?$ \\
\hline 26 & 45 & 20 & 11 & 64,5 & neritik luar \\
\hline 27 & 44 & 60 & 288 & 17,2 & neritik dalam \\
\hline 28 & 43 & 46 & 352 & 11,6 & neritik dalam \\
\hline 29 & 42 & 2 & 2 & $?$ & $?$ \\
\hline 30 & 41 & 264 & 1712 & 13,4 & neritik dalam \\
\hline & Jumlah & 23276 & 34025 & & \\
\hline \multicolumn{3}{|c|}{ Jumlah Total } & 57301 & & \\
\hline
\end{tabular}

Rasio foraminifera plangtonik dan foraminifera bentonik (rasio P/B) dapat menunjukkan zona lingkungan dan zona batimetri suatu daerah. Hasil penghitungan rasio $\mathrm{P} / \mathrm{B}$ pada Tabel 2 menunjukkan adanya perubahan rasio $\mathrm{P} / \mathrm{B}$ sepanjang Kala Miosen Awal. Rasio P/B tertinggi tercapai pada sampel 48 yaitu sebesar $74 \%$.
Berdasarkan hasil rasio $\mathrm{P} / \mathrm{B}$, lingkungan daerah penelitian terdiri dari lingkungan laut dangkal (neritik) dan lingkungan laut dalam (oseanik). Lingkungan laut dangkal terdiri dari zona batimetri neritik dalam, neritik tengah dan neritik luar, sedangkan lingkungan laut dalam hanya terdiri dari zona batimetri batial atas. 
Fauzielly / Paleobatimetri Formasi Jatiluhur Berdasarkan Kumpulan Foraminifera Kecil pada Lintasan Sungai Cileungsi, Kabupaten Bogor, Jawa Barat

\begin{tabular}{|c|c|c|c|c|c|}
\hline \multirow[t]{3}{*}{ UMUR } & \multirow[t]{2}{*}{ LITOLOGI } & \multicolumn{4}{|c|}{ LINGKUNGAN \&ZONA BATIMETRI } \\
\hline & & & NERITIK & & OSEANIK \\
\hline & & $\begin{array}{l}\text { Neritik } \\
\text { Dalam }\end{array}$ & $\begin{array}{l}\text { Neritik } \\
\text { Tengah }\end{array}$ & $\begin{array}{c}\text { Neritik } \\
\text { Luar }\end{array}$ & Batial Atas \\
\hline & 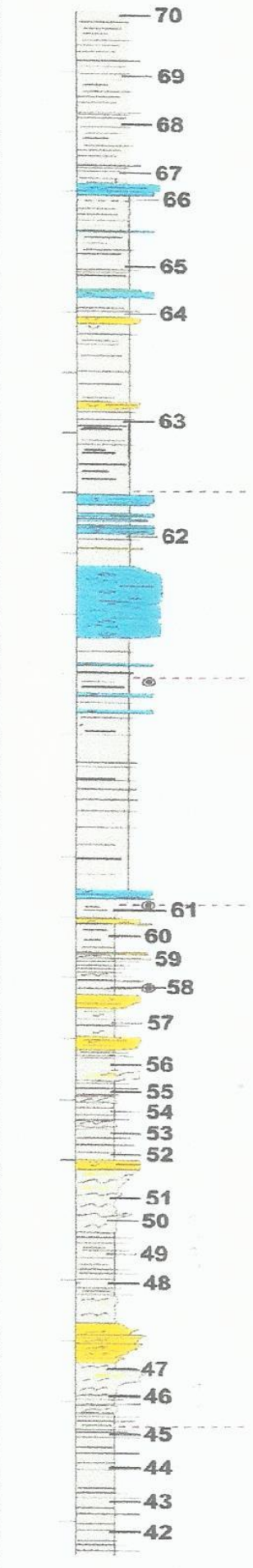 & ? & & ? & \\
\hline
\end{tabular}

Gambar 4. Grafik perubahan paleobatimetri daerah penelitian berdasarkan rasio foraminifera plangtonik dan bentonik kecil. 
Terjadi beberapa kali perubahan zona batimetri sepanjang Kala Miosen Awal bagian bawah pada Lintasan Sungai Cileungsi (Tabel 3) dimulai dari neritik dalam berubah mendalam menjadi neritik luar, kemudian berubah lagi menjadi lebih dalam yaitu batial atas. Setelah itu, terjadi perubahan zona batimetri yang sangat mencolok yaitu dari batial atas menjadi zona neritik tengah dan terus mendangkal menjadi zona neritik dalam. Dari zona neritik dalam kembali zona batimetri berubah mendalam menjadi zona neritik tengah, kemudian mendangkal menjadi zona neritik dalam dan setelah itu kembali lagi mendalam menjadi zona neritik tengah. Selanjutnya zona batimetri mendalam terus menjadi zona neritik tengahneritik luar. Memasuki Kala Miosen Awal Bagian Atas perubahan zona batimetri relatif lebih stabil dibandingkan dengan Kala Miosen Awal Bagian Bawah. Diawali dengan zona neritik dalam kemudian berubah menjadi neritik tengah dan selanjutnya kembali mendangkal menjadi neritik dalam, setelah itu mendalam secara mencolok menjadi zona neritik luar, neritik tengah-neritik luar dan terakhir berubah kembali menjadi zona neritik luar (Gambar 4).

Perubahan zona batimetri yang terjadi pada suatu daerah dapat disebabkan oleh beberapa faktor diantaranya adalah perubahan muka laut, tektonik dan perubahan iklim. Effendi et al., (1998) menyatakan struktur geologi yang berkembang pada daerah penelitian berupa sesar, lipatan, kelurusan dan kekar yang ditemukan pada batuan berumur Oligosen-Miosen-Pliosen sampai Kuarter. Berdasarkan pernyataan tersebut dapat diperkirakan perubahan zona batimetri pada Kala Miosen Awal disebabkan adanya struktur-struktur geologi.

\section{KESIMPULAN}

Paleobatimetri Formasi Jatiluhur pada lintasan Sungai Cileungsi terdiri dari zona batimetri neritik (lingkungan laut dangkal) dan zona batimetri oseanik (lingkungan laut dalam). Selama Kala Miosen Awal terjadi 13 kali perubahan zona batimetri dimulai dari neritik dalam-neritik luarbatial atas-neritik tengah-neritik dalam-neritik tengah-(neritik tengah-neritik luar)-neritik dalamneritik tengah- neritik dalam-neritik luar-(neritik tengah-neritik luar) dan neritik luar.

Perubahan zona batimetri terjadi secara mencolok dari lingkungan neritik (laut dangkal) menjadi lingkungan oseanik (laut dalam) pada Kala Miosen Awal Bagian Bawah dan dari zona neritik dalam menjadi zona neritik luar pada Kala Miosen Awal Bagian Atas diperkirakan disebabkan oleh berkembangnya struktur-struktur geologi yang terjadi di daerah penelitian.

\section{UCAPAN TERIMA KASIH}

Penelitian ini merupakan bagian dari Riset Fundamental yang didanai oleh HIU UNPAD 2017. Penulis mengucapkan terimakasih kepada Direktorat Riset PKM dan Inovasi Unpad beserta jajarannya.

\section{DAFTAR PUSTAKA}

Abdurrokhim, 2014. A Prograding Slope-Shelf Succsesion of The Middle-Late Miocene Jatiluhur Formation. Dissertation. Graduate School of Science. Chiba University.

Berggren, W. A., 1998. Marine Micropaleontology: An Introduction. Dalam Haq, B.U., dan Boersma, A. (Editor) 1998. Introduction to Marine Micropaleontology. 5th printing. Elsevier Science Publishing Co., Inc. New York.

Boltovskoy, E., dan Wright, R., 1976. Recent Foraminifera. Dr. W.Junk b.v. publishers the Hague.

Effendi, A. C., Kusnama dan Hermanto, B., 1998. Peta geologi Lembar Bogor, Jawa. Skala 1: 100.000, edisi kedua, Kementerian Energi dan Sumber Daya Mineral.

Jones, R. W., 2014. Foraminifera and Their Applications. Cambridge University Press. United Kingdom.

Jurnaliah, L., 2006. Paleoekologi Satuan Batulempung Formasi Jatiluhur, Daerah Cileungsi, Kab. Bogor, Jawa Barat. Bulletin of Scientific Contribution, 4(1), 78-87. ISSN 1693-4873.

Lipps, J. H., 1979. Foraminiferal Ecology and paleoecology. SEPM Short Course No. 6. Houston.

Loeblich, A. R., dan Tappan, H., 1994. Foraminifera of the Sahul Shelf and Timor Sea. Special Publication no. 31. Cushman Foundation For Foraminiferal research Inc. Department of Invertebrate Paleontology. Harvard University. Cambridge, USA. 
Mendes, I., Gonzales, R., Dias, J. M. A., Lobo, F., dan Martins, V., 2004. Factors Influencing Recent Benthic Foraminifera Distribution on The Guadiana Shelf (Southwestern Iberia). Marine Microplaeontology 51, 171-192.

Mulyasari, F., 1999. Geologi dan Biostratigrafi Pada Satuan Batulempung Formasi Jatiluhur Daerah Cileungsi dan sekitarnya, Kecamatan Cileungsi, Propinsi Jawa Barat. Universitas Padjadjaran, Fakultas Matematika dan Ilmu Pengetahuan Alam, Jurusan Geologi, Jatinangor.

Murray, J., dan Rohling, E. J., 2012. Foraminifera. https://www.noc.socton.ac. uk. National Oceanography Centre Southampton.

Reza, S. E. V., Jurnaliah, L., dan Abdurrokhim. 2016. Biostratigraphy Correlation of Jatiluhur, Kalapanungggal, and Subang Formation in Northern Part of Bogor Through. Proceedings Geosea XIV and 45TH IAGI Convention 2016. Bandung. October 10-13. p. 424-425.
Todd, R., Low, D., dan Mello, J. F., 1965. Smaller Foraminifera dalam Kummel, B. dan Raup, D (Editor). 1965. Handbook of Paleontological Techniques. W.H. Freeman Company. San Fransisco \& London.

Valchev, B., 2003. On The Potential of Small Benthic Foraminiferal as Paleoecology indicators: Recent Advances. 50 Years University of Mining and geology "St. Ivan Rilski”. Annual. Geology and geophysics, Sofia. 46(I), 189-194.

Van Marle, L. J., 1989. Benthic Foraminifera From Banda Arc Region, Indonesia, and Their Paleobathymetric Significance For Geologic Interpretations of The Late Cenozoic Sedimentary Record. Free University Press, Amsterdam. 